\title{
Contents of constituents and antioxidant activity of seed and pulp extracts of Annona coriacea and Annona sylvatica
}

\author{
Benites, RSR. ${ }^{a}$ Formagio, ASN. $^{\text {** }}$, Argandoña, EJS. ${ }^{a}$, Volobuff, $C R F^{c}$, \\ Trevizan, LNF., Vieira, MC. ${ }^{b}$ and Silva, MS. ${ }^{c}$ \\ ${ }^{a}$ Faculdade de Ciências Exatas e Tecnologia, Universidade Federal da Grande Dourados - UFGD, \\ Itahum, Km 12, CP 533, CEP 79804-070, Dourados, MS, Brazil \\ ${ }^{b}$ Faculdade de Ciências Agrárias, Universidade Federal da Grande Dourados - UFGD, \\ Itahum, Km 12, CP 533, CEP 79804-070, Dourados, MS, Brazil \\ 'Faculdade de Ciências Biológicas e Ambientais, Universidade Federal da Grande Dourados - UFGD, \\ Itahum, Km 12, CP 533, CEP 79804-070, Dourados, MS, Brazil \\ *e-mail: aneliseformagio@ufgd.edu.br
}

Received: November 13, 2013 - Accepted: May 16, 2014 - Distributed: August 31, 2015

\begin{abstract}
The antioxidant potential of fruit pulp and seeds of extracts of the Annona coriacea, and A. sylvatica (Annonaceae) were investigated, as well contents total phenolics, flavonoids, condensed tannins and ascorbic acid. Was used to determine the antioxidant activity the 1,1-diphenyl-1-picrylhydrazyl free radical (DPPH), $\beta$-carotene bleaching and ABTS radical cation method. The total phenol, total flavonoid, condensed tannin, and ascorbic acid contents were measured spectrophotometrically. In this study, the pulp and seeds of the fruits were extracted using methanol/water (8:2) for maceration. The seed extracts of $A$. coriacea demonstrated a moderate antioxidant effect with free radical scavenging activity of $31.53 \%$, by the DPPH test, $51.59 \%$ by the $\beta$-carotene bleaching test and $159.50 \mu \mathrm{M}$ trolx $/ \mathrm{g}$ of extract in the ABTS assay. We found that the hydromethanolic seed extract of $A$. coriacea had high total phenol $(147.08 \pm 4.20 \mathrm{mg}$ of GAE/g of extract) and flavonoid (131.18 $\pm 2.31 \mathrm{mg}$ of QE/g of extract) content. This indicated that the antioxidant activity of the extracts was related to the contents of these constituents.
\end{abstract}

Keywords: Annona, antioxidant activity, phytochemistry.

\section{Conteúdo de constituintes e atividade antioxidante de extratos de semente e polpa de Annona coriacea e Annona sylvatica}

\section{Resumo}

O potencial antioxidante de extratos da polpa e sementes de frutos da Annona coriacea e A. sylvatica (Annonaceae) foram investigados, bem como os teores de fenóis totais, flavonóides totais, ácido ascórbico total e taninos condensados. Os métodos utilizados para avaliação da atividade antioxidante foram o 1,1-difenil-2-picrilhidrazil (DPPH) branqueamento do $\beta$-caroteno e ensaio do radical ABTS. O teor de fenóis totais, flavonoides totais, taninos condensados e ácidos ascórbico foram determinados utilizando espectrofotômetro. A polpa e as sementes dos frutos foram extraídas por maceração com metanol/água (8:2). O extrato da semente de $A$. coriacea demonstrou moderado efeito antioxidante, com $31,53 \%$ no sequestro de radicais livres pelo ensaio do DPPH, $51,59 \%$ pelo teste do branqueamento do $\beta$-caroteno e pelo ensaio do ABTS com 159,50 $\mu \mathrm{M}$ trolox/g de extrato. Foi observado que o extrato hidrometanólico das sementes de $A$. coriacea obteve alto teor de fenóis totais (147,08 $\pm 4,20 \mathrm{mg}$ of GAE/g de extrato) e flavonóides totais $(131,18 \pm 2,31 \mathrm{mg}$ of $\mathrm{QE} / \mathrm{g}$ de extrato). Isto indica que atividade antioxidante dos extratos pode estar relacionada com o teor destes constituintes.

Palavras-chave: Annona, atividade antioxidante, fitoquímica.

\section{Introduction}

Free radicals and other oxidants have been associated with being responsible for the development of a number of chronic and degenerative diseases such as cancer, cardiovascular diseases, cataract, Alzheimer's, aging, immune system decline, and cerebral disorders (Atoui et al., 2005; Barreiros et al., 2006; Sian, 2003). The production of free radicals is controlled in living things by several antioxidant

compounds, which can come from the diet and other sources (Alasalvar et al., 2005; Atoui et al., 2005). These fruits have attracted considerable attention as a source of natural antioxidants.

The genus Annona (Annonaceae) consists of 250 species distributed across Brazil, and has a great variety of of fleshy, odorous and tathy fruits, known as "araticum" or 
"marolo", widely consumed "in natura" and used by the population to prepare juice, ice-cream or jelly (Silva and Tassara, 2001). The other parts of the fruit are also widely used in folk medicine for antiparasitic or antitumoral treatment of intestinal diseases. The infusion of leaves and powdered seeds is used to combat diarrhea and induce menstruation (Almeida et al., 1994; Silva et al., 1994). In Brazil, A. coriacea, "marolo", is popular used against chronic diarrhea (Rodrigues and Carvalho, 2001), antimalarial (Mesquita et al., 2007), anti-helmintic (Santos and Sant'Ana, 2000, 2001), and leishmaniasis (Akendengue et al., 1999). The leaves of the A. sylvatica, "araticum da mata", are used to treat malaria or as a febrifuge (Balbach, 1986). On consulting the literature, no reports on the comparative studies of the antioxidant activities of A. coriacea or A. sylvatica were found.

Methods were developed for a quick, simple, and reliable quantification of the antioxidant capacity. In general, the methods were divided into two major groups: Assays based on a single electron transfer (SET) reaction, with a change in color as the oxidant is reduced, and assays based on a hydrogen atom transfer (HAT) (Huang et al., 2005), which measures the activity of the antioxidant to scavenge the peroxyl radicals, such as, the total radical trapping antioxidant parameter (TRAP) assay, the oxygen radical absorbance capacity (ORAC) assay, and the luminol-chemiluminescence-based peroxyl radical scavenging capacity (LPSC) assay (Alho and Leinonen, 1999; Huang et al., 2005; Ou et al., 2001). The assays electron transfer includes the reaction of ferric reduction (FRAP), the $\alpha$-tocopherol/Trolox equivalent antioxidant capacity (TEAC), and the 1,1-diphenyl-2-picrylhydrazyl (DPPH) (Benzie and Strain, 1996; Brand-Williams et al., 1995; Huang et al., 2005; Re et al., 1999).

The beneficial effects of the plant food are attributed to the variety of their phytochemistry including the polyphenols, which have revealed a remarkable spectrum of biochemical and pharmacological actions, thought to be due to their antioxidative and free-radical scavenging properties (Noroozi et al., 1998)

In the present study, we evaluated the antioxidant activity of Annona coriacea and A. sylvatica fruits (pulp and seeds), measured by DPPH, $\beta$-carotene bleaching, and the ABTS radical cation method, in our search for natural antioxidants. In addition, a number of parameters were determined to characterize this activity, among which are: Total polyphenols (TPP), total flavonoids (TF), condensed tannins (CT), and ascorbic acid content (TAA).

\section{Material and Methods}

\subsection{Plant material and extract preparation}

The fruits of A. coriacea Mart. and A. sylvatica A. St. -Hil. were collected in December 2011, in Dourados, in the state of Mato Grosso do Sul, Brazil, which is located at an average altitude of $452 \mathrm{~m}$; at $23^{\circ} 17^{\prime} 6^{\prime \prime} \mathrm{S}$ latitude and $54^{\circ} 43^{\prime} 28^{\prime \prime} \mathrm{W}$ longitude. The plants were identified by Dr. Zefa Valdevina Pereira, who is a Professor at the University Federal of the
Grande Dourados, and a voucher specimen was deposited at the Herbarium of this University, A. coriacea (DDMS 186) and $A$. sylvatica (DDMS 4600). For preparing the extracts, the fruit pulp and air-dried and powdered seeds of each species were separately and successively extracted by maceration with methanol/water (8:2), at room temperature. The extract was filtered, concentrated under pressure in a rotaevaporator at $50^{\circ} \mathrm{C}$, and lyophilized. The extraction yield of the crude extracts was determined from the mass of the material prior to extraction and the mass of extract obtained after removal of methanol/water. The extraction yield was calculated in percentage after weighing.

\subsection{Chemicals}

2,4-Dinitrophenylhydrazine (DNPH), 1,1-Diphenyl2-picrylhydrazyl (DPPH), butylated hydroxyltoluene (BHT), 2,2-azinobis (3-ethyl-benzothiazoline-6-sulfonic acid (ABTS), 6-hydroxy-2,5,7,8-tetramethylchroman-2carboxylic acid (Trolox), quercetin, catechin, and $\beta$-carotene were obtained from Sigma Chemical Co. (MO, USA). Potassium persulfate, tween 40, Folin-Ciocalteau, sodium carbonate from Dinamina, sulfuric acid, methanol, ethanol, hydrochloric acid, ascorbic acid, chloroform, linolenic acid, gallic acid, aluminum chloride, sodium acetate, and vanillin were obtained from Vetec (RJ, Brazil).

\subsection{Total phenol content}

The total phenol content of the samples was determined using the Folin-Ciocalteau reagent (Djeridane et al., 2006). Briefly, $100 \mu \mathrm{L}$ of extracts in methanol $(1 \mathrm{~g} / \mathrm{L})$ were mixed with $1.0 \mathrm{~mL}$ of distilled water and $0.5 \mathrm{~mL}$ of Folin-Ciocaleu's $(1: 10 \mathrm{v} / \mathrm{v})$ reagent. After mixing, $1.5 \mathrm{ml}$ of $2 \%$ sodium bicarbonate was added, and the mixture was allowed to stand for $30 \mathrm{~min}$ with intermittent shaking. The absorbance was measured at $765 \mathrm{~nm}$ using a spectrophotometer. The total phenolic content was expressed as a gallic acid equivalent (GAE) in milligrams per gram $(\mathrm{mg} / \mathrm{g})$ of extract. The methanol solution was used as a blank.

\subsection{Total flavonoid content}

The amount of total flavonoids in the extracts was measured spectrophotometrically, as reported (Lin and Tang, 2007). Briefly, $500 \mu \mathrm{L}$ of each extract was mixed with $1.50 \mathrm{~mL}$ of $95 \%$ ethanol, $0.10 \mathrm{~mL}$ of $10 \%$ aluminum chloride $\left(\mathrm{AlCl}_{3} .6 \mathrm{H}_{2} \mathrm{O}\right), 0.10 \mathrm{~mL}$ of acetate sodium $\left(\mathrm{NaC}_{2} \mathrm{H}_{3} \mathrm{O}_{2} \cdot 3 \mathrm{H}_{2} \mathrm{O}\right)(1 \mathrm{M})$, and $2.80 \mathrm{~mL}$ of distilled water. After incubation for $40 \mathrm{~min}$, the absorbance was measured at $415 \mathrm{~nm}$, using a spectrophotometer. To calculate the concentration of flavonoids, we prepared a calibration curve by using quercetin as the standard. The flavonoid content was expressed as quercetin equivalents $(\mathrm{QE})$ in milligrams per gram $(\mathrm{mg} / \mathrm{g})$ of extract.

\subsection{Condensed tannin content}

Condensed tannin concentrations were determined by a modified version of the method developed by Maxson and Rooney (1972). The samples were mixed with $5 \mathrm{~mL}$ of the vanillin- $\mathrm{HCl}$ reagent $(8 \%$ concentrated $\mathrm{HCl}$ in methanol and $4 \%$ vanillin in methanol). The absorbance at $500 \mathrm{~nm}$ 
was read after $20 \mathrm{~min}$. Catechin was used as reference. The condensed tannin content was expressed as catechin equivalents $(\mathrm{CE})$ in milligrams per gram $(\mathrm{mg} / \mathrm{g}$ ) of extract.

\subsection{Ascorbic acid content}

The determination of TAA was adapted from the spectrophotometric method developed by Roe and Kuether (1943), for the estimation of ascorbic acid content. A sample of $0.1 \mathrm{~mL}$ (100 mg extract/10 mL methanol HPLC) was added to 2, 4 dinitrophenylhydrazine reagent (2,4-DNPH). It was allowed to stand for 30 minutes and the absorbance was read in triplicate at $515 \mathrm{~nm}$, using distilled water as blank. The result was expressed in milligrams of ascorbic acid per gram of extract.

\subsection{DPPH free radical scavenging assay}

Free radical scavenging activities of the test samples and of the positive control butylhydroxytoluene (BHT) were determined using the DPPH free radical method (Blois, 1958). Various concentrations of the samples were added to $3 \mathrm{~mL}$ of methanol DPPH solution $(0.1 \mathrm{mM})$ prepared daily. The mixture was shaken and left to stand at room temperature, in the dark. After $30 \mathrm{~min}$, the absorbance was measured at $517 \mathrm{~nm}$ against a blank (containing all reagents except the test samples). The assays were carried out in triplicate. The concentrations of the samples for $50 \%$ inhibition of DPPH $\left(\mathrm{IC}_{50}\right)$ were obtained from the graph of I\% (inhibition percentage) versus a concentration of the sample in microgram per milliliter $(\mu \mathrm{g} / \mathrm{mL})$. I\% was calculated using the equation: $\mathrm{I} \%=\left(\mathrm{A}_{\text {blank }}-\mathrm{A}_{\text {sample }} / \mathrm{A}_{\text {blank }}\right)$ $\times 100$, where $A_{\text {blank }}$ is the absorbance of the blank solution and $\mathrm{A}_{\text {sample }}$ is the absorbance of the test sample.

\section{8. $\beta$-Carotene bleaching test}

The $\beta$-carotene solution was prepared by dissolving $2 \mathrm{mg}$ of $\beta$-carotene in $10 \mathrm{~mL}$ of chloroform. $1 \mathrm{~mL}$ of $\beta$-carotene-chloroform solution was mixed with $20 \mathrm{mg}$ linoleic acid and $0.2 \mathrm{~g}$ Tween 40 . Subsequently, the chloroform was removed by a rotary evaporator at $45^{\circ} \mathrm{C}$. Distilled water $(50 \mathrm{~mL})$ was slowly added with vigorous agitation to form an emulsion. Emulsion aliquots $(5 \mathrm{~mL})$ were transferred with $0.2 \mathrm{~mL}$ of sample extracts. The control samples were prepared with $0.2 \mathrm{~mL}$ methanol instead of extracts (Jayaprakasha et al., 2001; Kaur and Kapoor 2002; Shahidi et al., 2001). As soon as the emulsion was added to each tube, zero time absorbance was read at $470 \mathrm{~nm}$ against the blank. The tubes were placed in a water bath at $50^{\circ} \mathrm{C}$ and the oxidation of the emulsion was monitored by the subsequent reading of absorbance at $15 \mathrm{~min}$ intervals, until the color of the $\beta$-carotene in the control sample had disappeared (105 min). BHT was used as reference. Analyses were performed in triplicate. The antioxidant activity (AA) was calculated as a percent of inhibition, relative to the control, using the following equation: $\mathrm{AA}=\left[1-(\mathrm{Ai}-\mathrm{At}) /\left(\mathrm{A}^{\prime} \mathrm{i}-\mathrm{A}^{\prime} \mathrm{t}\right)\right] \times 100$, where $\mathrm{A} \mathrm{i}=$ absorbance of the sample at zero time; $\mathrm{At}=$ absorbance of the sample after incubation $(105 \mathrm{~min})$ at $50^{\circ} \mathrm{C} ; \mathrm{A}^{\prime} \mathrm{i}=$ absorbance of the control at zero time; $A^{\prime} t=$ absorbance of control after incubation $(105 \mathrm{~min})$ at $50^{\circ} \mathrm{C}$.

\subsection{ABTS assay}

The total antioxidant activity was measured by the improved azino-bis (ethylbenzothiazoline6-sulfonicacid) radical scavenging (ABTS) method (Rufino et al., 2007), with minor modifications. Briefly, $7.0 \mathrm{mM} \mathrm{ABTS}$ and $140 \mathrm{mM}$ potassium persulfate were mixed for the production of the ABTS cation (ABTS) and kept in dark for 16 hours, at ambient temperature. The ABTS solution was diluted with ethanol (P.A.) till the absorbance obtained $0.700( \pm 0.05)$, at $734 \mathrm{~nm}$. For sample analysis, $3 \mathrm{~mL}$ of diluted ABTS solution was added to $30 \mu 1$ of five different dilutions of the methanolic extract and mixed thoroughly. The reaction mixture was allowed to sit $(6 \mathrm{~min})$ in the dark, at an ambient temperature, and absorbance was recorded at $734 \mathrm{~nm}$, using ethanol (P.A.) to the blank. A standard curve of various concentrations was prepared of ethanolic solution in trolox, in concentrations of: 100; 500; 1000, and $2000 \mu \mathrm{M}$. The results were expressed in $(\mu \mathrm{M})$ trolox equivalent per gram of extract.

\subsection{Statistical analysis}

All of the experiments were conducted in triplicate. The data shown represent the mean \pm standard deviation (SD) of three determinations. The $\mathrm{IC}_{50}$ value was determined by linear regression, using Origin 5.0.

\section{Results}

The seed and pulp extracts of fruits $A$. coriacea (14.5 and 20.5\%) and A. sylvatica (8.7 and 5.2\%) showed great extraction yield $(\% \mathrm{w} / \mathrm{w})$.

The seed extracts of $A$. coriacea demonstrated a moderate antioxidant effect and exhibited a free radical scavenging activity of $31.53 \%$, by the DPPH test. The seeds also afforded antioxidant activity (51.59\%) by the $\beta$-carotene bleaching test and $159.50 \mu \mathrm{M}$ trolox/g of extract in the ABTS assay (Table 1).

The total phenolic content, flavonoids, condensed tannins, and ascorbic acid of the extracts are shown in Table 2. The results show that the hydromethanolic seed extract of A. coriacea has the highest total phenolic content (147.08 $\pm 4.20 \mathrm{mg} \mathrm{GAE} / \mathrm{g}$ extract) and the highest flavonoid content (131.18 $\pm 2.31 \mathrm{mg} \mathrm{QE} / \mathrm{g}$ extract). In comparison, the evaluated condensed tannin and ascorbic acid contents of the extracts are low (Table 2).

\section{Discussion}

Ascorbic acid is, structurally, a simplest vitamin components found in plants. Is a sugar acid lactone. It is synthesized in plants from glucose or other simple carbohydrates (Kays, 1991). Ascorbic acid concentrations determined in this study for A. coriacea and A. sylvatica were lower than those reported in other Annona species; e.g., A. cherimolia, 4-6 mg/100g (Vasco et al., 2008); A. muricata, $4 \mathrm{mg} / 100 \mathrm{~g}$ (Duke and DuCellier, 1993); A. diversifolia, $2.38 \mathrm{mg} / 100 \mathrm{~g}$ (Julián-Loaeza et al., 2010); and A. squamosa, $15-35 \mathrm{mg} / 100 \mathrm{~g}$ (Andrade et al., 2001). However, species of Annona feature equivalent content 
Table 1. Antioxidant activity of the four extracts of Annona fruits by DPPH, $\beta$-carotene bleaching, and ABTS test.

\begin{tabular}{|c|c|c|c|c|c|}
\hline \multirow[t]{3}{*}{ Species } & & \multicolumn{4}{|c|}{ Test } \\
\hline & & \multicolumn{2}{|c|}{ DPPH } & \multirow{2}{*}{$\begin{array}{c}\beta \text {-carotene/linoleic } \\
\text { acid }\end{array}$} & \multirow{2}{*}{$\begin{array}{c}\text { ABTS } \\
(\mu \mathrm{M} \text { trolox/g extract) }\end{array}$} \\
\hline & & $\mathrm{IC}_{50} \mu \mathrm{g} / \mathrm{mL}$ & $\%$ FRS $*$ & & \\
\hline \multirow{2}{*}{ A. coriacea } & Pulp & $822.19 \pm 13.89$ & $13.49 \pm 2.83$ & $32.32 \pm 4.02$ & $57.18 \pm 4.0$ \\
\hline & Seeds & $330.55 \pm 2.34$ & $31.53 \pm 1.65$ & $51.59 \pm 6.43$ & $159.36 \pm 8.32$ \\
\hline \multirow{2}{*}{ A. sylvatica } & Pulp & $695.61 \pm 6.67$ & $11.82 \pm 1.06$ & $31.17 \pm 5.83$ & $39.15 \pm 4.43$ \\
\hline & Seeds & $724.14 \pm 17.79$ & $16.70 \pm 1.06$ & $12.82 \pm 3.96$ & $135.50 \pm 8.94$ \\
\hline BHT & & $16.72 \pm 1.87$ & $82.19 \pm 1.29$ & $91.20 \pm 4.54$ & n.d. \\
\hline
\end{tabular}

Values are expressed as mean $\pm \mathrm{SD}(\mathrm{n}=3)$; n.d. $=$ not determined. $\mathrm{IC}_{50}=$ corresponds to the concentration of $50 \%$ inhibition of $\mathrm{DPPH}$ and is calculated from the graph of $\mathrm{I} \%$ (inhibition percentage) versus extract concentration in $\mu \mathrm{g} / \mathrm{mL} . * \% \mathrm{FRS}=$ free-radical scavenging percentage (*antioxidant activity evaluated by the method of DPPH free-radical scavenging, with the final concentration equivalent to $250 \mu \mathrm{g} / \mathrm{mL}$ of extract).

Table 2. Contents of constituents of four extracts of Annona fruits.

\begin{tabular}{cccccc}
\hline Species & Extracts & & \multicolumn{2}{c}{$\begin{array}{c}\text { Levels of constituents } \\
\text { (mg/g of the extract) }\end{array}$} & \\
\hline & & Total Phenols & Flavonoids & $\begin{array}{c}\text { Condensed } \\
\text { tannins }\end{array}$ & Ascorbic acid \\
\hline \multirow{2}{*}{ A. coriacea } & Pulp & $57.67 \pm 1.16$ & $24.38 \pm 2.45$ & $17.43 \pm 1.08$ & $0.56 \pm 1.58$ \\
\cline { 2 - 6 } A. sylvatica & Seeds & $147.08 \pm 4.2$ & $131.18 \pm 2.31$ & $45.76 \pm 0.97$ & $0.65 \pm 1.06$ \\
\cline { 2 - 6 } & Pulp & $13.64 \pm 2.18$ & $13.74 \pm 2.18$ & $15.68 \pm 2.04$ & $0.95 \pm 2.26$ \\
\hline
\end{tabular}

of vitamin $\mathrm{C}$ when compared to other fruits consumed as tomato, peach and others (Arbos et al., 2010; Chitarra and Chitarra, 1990).

According to Pereira et al. (2013), the pulp of A. sylvatica has $8.84 \mathrm{~g}$ of sugar content, $17.89 \mathrm{~g}$ of carbohydrates, $1.82 \mathrm{~g}$ of protein, and $8.74 \mathrm{~g}$ of total fiber. The A. coriacea pulp content has $11.91 \mathrm{~g}$ of carbohydrates, $1.07 \mathrm{~g}$ of protein, and $5.62 \mathrm{~g}$ of total fiber (Hiane et al., 1992).

The DPPH free radical scavenging assay is based on the ability of certain substances to donate a hydrogen atom to the radical, reducing it to hydrazine, provoking a change in coloration, from pale yellow to violet. This change is accompanied by the fall in coloring of the $517 \mathrm{~nm}$ absorbance (Alves et al., 2010). The test of inhibition of the autoxidation of $\beta$-carotene/linoleic acid is based on the ability of certain substances to protect the beta-carotene from oxidation. This oxidation is caused by the free radicals formed during the peroxidation of linoleic acid, which attack the chromophore of the $\beta$-carotene emulsion resulting in a whitening reaction (Alves et al., 2010; Damasceno et al., 2011).

The antioxidant activity of vegetable extracts depends on the type and polarity of the extracting solvent, the isolation procedures, and the purity of the active compounds, as well as the assay techniques and substrate used (Meyer et al., 1998). Generally polar solvents provide slightly more active extracts than mixtures with less polar solvents. This factor may also have affected the results when using the methanol/water solvent, providing greater extraction of components.
Several studies that included the species of Annona report excellent antioxidant activity, such as, the leaves of $A$. dioica (Formagio et al., 2013); leaves, bark, roots, and seedcake of $A$. squamosa (Baskar et al., 2007; Mariod et al., 2012; Shirwaikar et al., 2004); pulp, seeds, and peel of $A$. crassiflora (Roesler et al., 2006; 2007); bark and leaves of Annona salzmannii (Costa et al., 2011, 2012a); leaves of A. reticulata and A. muricata (Baskar et al., 2007; Melo et al., 2010); leaves of $A$. senegalensis (Ajboye et al., 2010); leaves of A. pickelii (Costa et al., 2011); and leaves of $A$. vepretorun (Costa et al., 2012b).

It has been suggested that the phenolic content of plant materials is correlated to their antioxidant activity (Velioglu et al., 1998). In this study, we found that the hydromethanolic seed extracts of $A$. coriacea had the best radical scavenging activity, with high total phenol and flavonoid content. This indicates that the antioxidant activity of the extracts is related to the contents of these constituents.

Phenolic compounds are considered to be secondary metabolites that are synthesized by plants during normal development, in response to stress conditions, and the compounds occur ubiquitously in plants as a diversified group of phytochemicals derived from phenylalanine and tyrosine. In food, phenolics may contribute to the bitterness, astringency, color, flavor, odor, and oxidative stability of the products. In addition, they have numerous beneficial effects, such as, free radical scavenging oxygen species, modulate the activity of some specific enzymes, inhibit cell proliferation, and have antimicrobial, anti-inflammatory, and anti-allergic potential (Manach et al., 2004). 
According Sousa et al. (2007), the phenolic compounds are distributed in the following categories: Simple phenolics, phenolic acids (benzoic and cinnamic acid derivatives), coumarins, flavonoids, hydrolysable and condensed tannins, stilbenes, lignans, and lignins. They have the ability to inhibit lipid peroxidation and lipoxygenase in vitro. Consumption of flavonoid containing fruits and vegetables has been linked to protection against cancer and heart disease (Hertog et al., 1992; Atoui et al, 2005).

The tannins condensed are polymers of flavonoids, whose structure is formed by connecting the series of monomers of units flavan-3-ol, or a derivative of this. This binding occurs usually between the 4 carbons of a structure and another 8. Variations may occur for different numbers monomers attached, for the occurrence of links for oxygenation pattern in the rings A and B of flavan-3-ol unit and the stereochemistry of substituent the $\mathrm{C}$ ring. The hydrolysable tannins are esters of gallic acid and hexahydroxydiphenic acid and glucose, as well as other polyols. Are soluble in water, potent antioxidants and responsible for the astringency of many fruits, through complexation of tannins and proteins. Our values have been relatively equivalent compared to many other fruits of different families present in Cerrado ecosystem (Rocha et al., 2011).

In conclusion, our study has demonstrated the moderate antioxidant properties of the seed extracts of Annona coriacea and shown that this effect can be attributed to the total phenols and flavonoid content. Further studies on isolation and structure elucidation of active components from the extract, as well as, investigations of their inhibitory mechanism are needed. In addition, the results reported in this paper may contribute to the appreciation of the nutrimental and functional value of $A$. sylvatica and $A$. coriacea fruits.

\section{Acknowledgements}

This study was supported by UFGD, Fundect, and Capes.

\section{References}

AJBOYE, TO., YAKUBU, MT., SALAU, AK., OLADIJI, AT., AKANJ, MA. and OKOGUN, JI., 2010. Antioxidant and drug detoxification potential of aqueous extract of Annona senegalensis leaves in carbon tetrachloride-induced hepatocellular damage. Pharmaceutical Biology, vol. 48, no. 12, p. 1361-1370.

AKENDENGUE, B., NGOU-MILAMA, E., LAURENS, A. and HOCQUEMILLER, R., 1999. Recent advances in the fight against leishmaniasis with natural products. Parasite, vol. 6, p. 3-8.

ALASALVAR, C., AL-FARSI, M., QUANTICK, PC., SHAHIDI, F. and WIKTOROWICZ, R., 2005. Effect of chill storage and modified atmosphere packaging (MAP) on antioxidant activity, anthocyanins, carotenoids, phenolics and sensory quality of readyto-eat shred- ded orange and purple carrots. Food Chemistry, vol. 89 , p. 69-76.
ALHO, H. and LEINONEN, J., 1999. Total antioxidant activity measured by chemiluminescence methods. Methods in Enzymology, vol. 299, p. 3-15.

ALMEIDA, SP., PROENÇA, CEB., SANO, SM. and RIBEIRO, JF., 1994. Cerrado: espécies vegetais úteis. Planaltina, DF: EMBRAPA-CPAC. p. 48-335.

ALVES, CQ., DAVID, JM., DAVID, JP., BAHIA, MV. and AGUIAR, RM., 2010. Métodos para determinação de atividade antioxidante in vitro em substratos orgânicos. Quimica Nova, vol. 33, no. 10, p. 2202-2210.

ANDRADE, EHA., ZOGHBI, MGB., MAIA, JGS., FRABICIUS, H., and MARX, F., 2001. Chemical characterization of the fruit of Annona squamosa L. occurring in the Amazon. Journal of Food Composition and Analysis, vol. 4, p. 227-232.

ARBOS, KA., FREITAS, RJS., STERTZ, SC. and CARVALHO, LA., 2010. Segurança alimentar de hortaliças orgânicas: aspectos sanitários e nutricionais. Ciência e Tecnologia de Alimentos, vol. 30, p. 215-220.

ATOUI, AK., MANSOURI, A., BOSKOU, G. and KEFALAS, P., 2005. Tea and herbal infusions: their antioxidant activity and phenolic profile. Food Chemistry, vol. 89, p. 27-36.

BALBACH, A., 1986. As plantas curam. São Paulo: Edel. 415 p.

BARREIROS, ALBS., DAVID, JM. and DAVID, JP., 2006. Estresse oxidativo: relação entre geração de espécies reativas e defesa do organismo. Quimica Nova, vol. 29, p. 113-123.

BASKAR, R., RAJESWARI, V. and KUMAR, TS., 2007. In vitro antioxidant studies in leaves of Annona species. Indian Journal of Experimental Biology, vol. 45, no. 5, p. 480-485.

BENZIE, IF. and STRAIN, JJ., 1996. The ferric reducing ability of plasma (FRAP) as a measure of "antioxidant power": the FRAP assay. Analytical Biochemistry, vol. 239, p. 70-76.

BLOIS, MS., 1958. Antioxidant determinations by the use of a stable free radical. Nature, vol. 26, p. 1199-1200.

BRAND-WILLIAMS, W., CUVELIER, ME. and BERSET, C., 1995. Use of a free radical method to evaluate antioxidant activity. Food Science and Technology, vol. 28, p. 25-30.

CHITARRA, MIF. and CHITARRA, AB., 1990. Pós-colheita de frutos e hortaliças: fisiologia e manuseio. Lavras: ESAL/ FAEPE. 320 p.

COSTA, EV., CRUZ, PE., LOURENÇO, CC., MORAES, VRS., NOGUEIRA, PCL. and SALVADOR, MJ., 2012a. Antioxidant and antimicrobial activities of aporphinoids and other alkaloids from the bark of Annona salzmannii A. DC. (Annonaceae). Natural Product Research, vol. 27, p. 1002-1006.

COSTA, EV., DUTRA, LM., NOGUEIRA, PCL., MORAES, VRS., SALVADOR, MJ., RIBEIRO, LH. and GADELHA, FR., 2012b. Essential oil from the leaves of Annona vepretorum: chemical composition and bioactivity. Natural Product Communications, vol. 7, no. 2, p. 265-266.

COSTA, EV., DUTRA, LM., JESUS, HC., NOGUEIRA, PCL., MORAES, VRS., SALVADOR, MJ., CAVALCANTI, SC., SANTOS, RL. and PRATA, AP., 2011. Chemical composition and antioxidant, antimicrobial, and larvicidal activities of the essential oils of Annona salzmannii and A. pickelii (Annonaceae). Natural Product Communications, vol. 6, no. 6, p. 907-912. 
DAMASCENO, EIT., SILVA, JKR., ANDRADE, EHA., SOUSA, PJC. and MAIA, JGS., 2011. Antioxidant capacity and larvicidal activity of essential oil and extracts from Lippia grandis. Brazilian Journal of Pharmacognosy, vol. 21, no. 1, p. 78-85.

DJERIDANE, A., YOUSFI, M., NADJEMI, B., BOUTASSOUNA, D., STOCKER, P. and VIDAL, N., 2006. Antioxidant activity of some algerian medicinal plants extracts containing phenolic compounds. Food Chemistry, vol. 97, p. 654-660.

DUKE, AT. and DUCELLIER, JL., 1993. CRC handbook of alternative cash crops. Boca Raton: CRC Press. p. 33-46.

FORMAGIO, AS., KASSUYA, CA., FORMAGIO NETO, F., VOLOBUFF, CR., IRIGUCHI, EK., VIEIRA, MC. and FOGLIO, MA., 2013. The flavonoid content and antiproliferative, hypoglycaemic, anti-inflammatory and free radical scavenging activities of Annona dioica St. Hill. BMC Complementary and Alternative Medicine, vol. 14, p. 1-8.

HERTOG, MGL., HOLLMAN, PCH. and VENEMA, DP., 1992. Optimization of a quantitative HPLC determination of potentially anticarcinogenic flavonoids in vegetables and fruits. Journal of Agricultural and Food Chemistry, vol. 40, p. 1591-1598.

HIANE, AP., RAMOS, MIL., RAMOS-FILHO, MM. and PEREIRA, JG., 1992. Composição centesimal e perfil de ácidos graxos de alguns frutos nativos do estado de Mato Grosso do Sul. Boletim do Centro de Pesquisa e Processamento de Alimentos, vol. 10 , p. $35-42$.

HUANG, D., OU, B. and PRIOR, RL., 2005. The chemistry behind antioxidant capacity assays. Journal of Agricultural and Food Chemistry, vol. 53, p. 1841-1856.

JAYAPRAKASHA, GK., SINGH, RP. and SAKARIAH, KK., 2001. Antioxidant activity of grape seed (Vitis vinifera) extracts on peroxidation models in vitro. Food Chemistry, vol. 73, p. 285-290.

JULIÁN-LOAEZA, AP., SANTOS-SÁNCHEZ, NF., VALADEZBLANCO, R., SÁNCHEZ-GUZMÁN, BS. and SALAS-CORONADO, R., 2010. Chemical composition, color, and antioxidant activity of three varieties of Annona diversifolia fruits. Industrial Crops and Products, vol. 34, p. 1262-1268.

KAUR, C. and KAPOOR, HC., 2002. Anti-oxidant activity and total phenolic content of some Asian vegetables. Journal of Food Science and Technology, vol. 37, p. 153-161.

KAYS, SJ., 1991. Postharvest phisiology of perishable plant products. New York: Avi Book. 532 p.

LIN, JY. and TANG, CY., 2007. Determination of total phenolic and flavonoid contents In selected fruits and vegetables, as well as their stimulatory effects on mouse splenocyte proliferation. Food Chemistry, vol. 101, p. 140-147.

MANACH, C., SCALBERT, A., MORAND, C., RÉMÉSY, C. and JIMÉNEZ, L., 2004. Polyphenols: food sources and bioavailability. The American Journal of Clinical Nutrition, vol. 79 , no. 5 , p. 727-747.

MARIOD, AA., ABDELWAHAB, SI., ELKHEIR, S., AHMED, YM., FAUZI, PN. and CHUEN, CS., 2012. Antioxidant activity of different parts from Annona squamosa, and Catunaregam nilotica methanolic extract. Acta Scientiarum Polonorum. Technologia Alimentaria, vol. 11, no. 3, p. 249-258.
MAXSON, ED. and ROONEY, LW., 1972. Evaluation of methods for tannin analysis in sorghum grain. Cereal Chemistry, vol. 49, p. 719-729.

MELO, JG., ARAÚJO, TAS., ALMEIDA E CASTRO, VTN., CABRAL, DLV., RODRIGUES, MD., NASCIMENTO, SC., AMORIM, ELC. and ALBUQUERQUE, UP., 2010. Antiproliferative activity, antioxidant capacity and tannin content in plants of semi-arid northeastern Brazil. Molecules, vol. 15, p. 8534-8542.

MESQUITA, ML., GRELLIER, P., MAMBU, L., PAULA, JE. and ESPINDOLA, LS., 2007. In vitro antiplasmodial activity of Brazilian Cerrado plants used as traditional remedies. Journal of Ethnopharmacology, vol. 110, p. 165-170.

MEYER, AS., HEINONEN, M. and FRANKEL, EN., 1998. Antioxidant interactions of catechin, cyanidin, cafeic acid, quercetin, and ellagic acid on human LDL oxidation. Food Chemistry, vol. 61, p. 71-75.

NOROOZI, M., ANGERSON, WJ. and LEAN, ME., 1998. Effects of flavonoids and vitamin C on oxidative DNA damage to human lymphocytes. The American Journal of Clinical Nutrition, vol. 67, p. $1210-1218$.

OU, B., HAMPSCH-WOODILL, M. and PRIOR, RL., 2001. Development and validation of an improved oxygen radical absorbance capacity assay using fluorescein as the fluorescent probe. Journal of Agricultural and Food Chemistry, vol. 49, p. 4619-4626.

PEREIRA, MC., STEFFENS, RS., JABLONSKI, A., HERTZ, PF., RIOS, AO., VIZZOTTO, M. and FLÔRES, SH., 2013. Characterization, bioactive compounds and antioxidant potential of three Brazilian fruits. Journal of Food Composition and Analysis, vol. 29, p. 19-24.

RE, R., PELLEGRINI, N., PROTEGGENTE, A., PANNALA, A., YANG, M. and RICE-EVANS, C., 1999. Antioxidant activity applying an improved ABTS radical cation decolorization assay. Free Radical Biology \& Medicine, vol. 26, p. 1231-1237.

ROCHA, WS., LOPES, RM., SILVA, DB., VIEIRA, RF., SILVA, JP. and AGOSTINI-COSTA, TS., 2011. Compostos fenólicos totais e taninos condensados em frutas nativas do cerrado. Revista Brasileira de Fruticultura, vol. 33, p. 1215-1221.

RODRIGUES, VEG. and CARVALHO, DA., 2001. Levantamento etnobotânico de plantas medicinais no domínio do Cerrado na região do Alto Rio Grande-MG. Ciências Agrotecnologicas, vol. 25, p. 102-123.

ROE, JH. and KUETHER, CA., 1943. The determination of ascorbic acid in whole blood and urine through the 2,4-dinitrophenylhydrazine derivative of dehydroascorbic acid. The Journal of Biological Chemistry, vol. 147, p. 399-407.

ROESLER, R., CATHARINO, RR., MALTA, LG., EBERLIN, MN. and PASTORE, G., 2007. Antioxidant activity of Annona crassiflora: Characterization of major components by electrospray ionization mass spectrometry. Food Chemistry, vol. 104, p. 1048-1054.

ROESLER, R., MALTA, LG., CARRASCO, LC. and PASTORE, G., 2006. Evaluation of the antioxidant properties of the Brazilian cerrado fruit Annona crassiflora (Araticum). Journal of Food Science, vol. 71, p. 102-107. 
RUFINO, MSM., ALVES, RE., BRITO, ES., MORAIS, SM., SAMPAIO, CG., PÉREZ-JIMÉNEZ, J. and SAURA-CALIXTO, FD., 2007. Metodologia cientifica: determinação da atividade antioxidante total em frutas pela captura do radical livre ABTS. Fortaleza: Embrapa. Comunicado Técnico.

SANTOS, AF. and SANT'ANA, AE., 2000. The molluscicidal activity of plants used in Brazilian folk medicine. Phytomedicine, vol. 6 , p. 431-438.

SANTOS, AF. and SANT'ANA, AE., 2001. Molluscicidal properties of some species of Annona. Phytomedicine, vol. 8, p. 115-120.

SHAHIDI, F., CHAVAN, UD., NACZK, M. and AMAROWICZ, R., 2001. Nutrient distribution and phenolic antioxidants in airclassified fractions of beach pea (Lathyrus maritimus L.). Journal of Agricultural and Food Chemistry, vol. 49, p. 926-933.

SHIRWAIKAR, A., RAJENDRAN, K. and KUMAR, CD., 2004. In vitro antioxidant studies of Annona squamosa Linn. leaves. Indian Journal of Experimental Biology, vol. 42, no. 8, p. 803-807.

SIAN, BA., 2003. Dietary antioxidants-past, present and future. Trends in Food Science \& Technology, vol. 14, p. 93-98.
SILVA, JA., SILVA, DB., JUNQUEIRA, NJ. and ANDRADE, LRM., 1994. Frutas nativas dos Cerrados. Brasília: Embrapa. p. $50-149$.

SILVA, S. and TASSARA, H., 2001. Frutas no Brasil. São Paulo: Empresa das Artes.

SOUSA, CMM., SILVA, HR., VIEIRA-JUNIOR, GM., AYRES, MCC., COSTA, CLS., ARAÚJO, DS., CAVALCANTE, LC., BARROS, EDS., ARAÚJO, PBM. and BRANDÃO, MS., 2007. Fenóis totais e atividade antioxidante de cinco plantas medicinais. Quimica Nova, vol. 30, p. 351-355.

VASCO, C., RUALES, J. and KAMAL-ELDIN, A., 2008. Total phenoliccompoundsand antioxidant capacities of major fruits from Ecuador. Food Chemistry, vol. 111, p. 816-823.

VELIOGLU, YS., MAZZA, G., GAO, L. and OOMAH, BD., 1998. Antioxidant activity and total phenolics in selected fruits, vegetables, and grain products. Agricultural and Food Chemistry, vol. 46, p. 4113-4117. 